\title{
28 Research Square \\ Reanalysis of the Revised EEDI Parameters for Inland Ships of Bangladesh
}

S M Rashidul Hasan ( $\square$ rashed.navalarch@gmail.com )

Bangladesh University of Engineering and Technology

Md. Mashud Karim

Bangladesh University of Engineering and Technology

Research Article

Keywords:

Posted Date: March 24th, 2022

DOI: https://doi.org/10.21203/rs.3.rs-1362921/v2

License: (c) (i) This work is licensed under a Creative Commons Attribution 4.0 International License. Read Full License 


\section{Abstract}

A revision of the Energy Efficiency Design Index (EEDI) formulation was previously proposed to be useful for inland ships of Bangladesh. The study had incorporated the shallow water effect using Schlichting's method, however, the evaluation and presentation of Schlichting's results did not cover all range of ship parameters. In addition to that, the previous proposal was not based on field studies and the consideration main engine's Maximum Continuous Rating (MCR) was not appropriate. This study has corrected the previously proposed EEDI formulation for inland ships of Bangladesh based on the physical investigation. In this regard, 15 inland ships of Bangladesh ( 05 cargo, 05 oil tanker and 05 passenger ships) have been physically investigated. The impact of shallow water effect on EEDI was assessed based on field study, which was compared with approved methods. It was assumed with reasonable considerations that the bank/restricted channel effects on the ship are negligible. The MCR was also fixed based on the field study. It was found that the deviations of Schlichting's results varied from $31.34 \%$ to $81.46 \%$ in comparison to the investigated results. The deviations of results calculated by Lackenby and Barras methods were varied from $10.10 \%$ to $43.83 \%$ and $-22.19 \%$ to $16.53 \%$ to the field studies. In addition to that, MCR has been measured for the same 15 ships. Investigated results show that the average MCR for inland cargo and oil tankers of Bangladesh is $70 \%$ whereas it is $80 \%$ for passenger ships. Based on the key findings of the field studies, a revised EEDI formulation is proposed for the inland ships of Bangladesh.

\section{Introduction}

The adopted EEDI formulation by IMO [1] to increase the energy efficiency of sea-going ships is successful so far [2]. In 2015, 932 million tonnes of $\mathrm{CO}_{2}$ were emitted globally from the maritime shipping sector, which is $2.6 \%$ of the global, which has been reduced from $2.9 \%$ of the global share from 2011 [3]. At the same time, inland shipping had only a $0.22 \%$ share of global shipping. Though the global share of $\mathrm{CO}_{2}$ emission from inland shipping is relatively very small (more than 11 times smaller) the absence of appropriate energy and emissions benchmark for Inland Waterway Self-Propelled ships is a large impediment to performance improvements of inland ships [4].

EEDI by IMO is not suitable for assessing the energy and environmental efficiency of inland navigation vessels [5]. In general, inland ships require more power at the same speed in comparison to similar types of open water/seagoing ships [6], primarily because of the shallow water effect. Since this effect varies with channel depth and width, a generalized EEDI reference line is not possible in a similar fashion to IMO.

Shallow and restricted water effects, different fuel qualities (to reduce operational cost), increase in engine power requirement, reduction in carrying capacity, cargo availability, etc. forbid the use of existing EEDI formulation for inland waterways of Bangladesh. Hasan and Karim [7] considered these. However, the procedure followed for shallow water effect calculation by Hasan and Karim was the famous Schlicting method [8]. The evaluation and presentation of Schlichting's results did not cover all range of ship parameters. The assumption of equal wave resistance by Schlichting in deep and shallow water when the lengths of the ship-generated waves are the same is questionable [9]. For the frictional resistance, Schlichting derived an empirical correction in terms of an assumed overspeed along the hull dependent on the ratio of 
Hull Midship Area and Depth of the water. However, its value was derived from his model-test data, to cover the remaining gap in total resistance after the wave correction had been made, and with some support from velocity measurements in the model basin. Now this wave resistance correction is a severe simplification. It assumes that ship waves propagate with the same speed as the ship, which is only true for transverse waves. Also, the wave resistance depends not just on wavelength but also on wave amplitude. An effect of additional sinkage in shallow water is disregarded. Therefore, the wave resistance correction cannot be expected to be accurate; and its deviations are implicitly incorporated in the frictional-resistance correction, found by correlating with the model-test data. Moreover, Schlichting's model tests were just for 3 cruisers of that era, with extreme slenderness and rather high speeds.

International Towing Tank Conference [10] approved two procedures for power trials in shallow water, namely Lackenby [11] and the Raven [12] methods. The Raven method does not provide any formulation, rather it is a procedure for a series of tests, which starts with CFD analysis. Later, this analysis is validated with model test and trial data. In practice, this is a very accurate process, but not a generalized process. In addition to that, the builder, owner, and verifier must agree upon this process, as stated in the ITTC guideline [10].

Lackenby [11] extended the well-known Schlichting method towards smaller effects and has cast it into a simpler form. This method is approved internationally and by ITTC and is much easier to be used for research purposes where many ships are under consideration. In the 7th Asia-Pacific Workshop on Marine Hydrodynamics [13] compared the experimental data to evaluate the Lackenby method. When CFD and experimental findings are compared, Lackenby's shallow water resistance yields a higher total resistance value. Raven [14] also mentions this result, stating that the Lackenby approach yielded greater total resistance estimates.

Barrass [15] on the other hand has produced a very simple formula and is easy to use for all channel configurations. However, his formula overestimates ship squat due to its simplicity. Moreover, using bigger squat values than real ones can be considered a precautionary measure in terms of navigation safety in shallow waters.

Though both Lackenby [11] and Barrass [15] methods have limitations, this research selected the method described by Lackenby for theoretical calculation which has been approved by ITTC [16]. In addition to that, the procedure as proposed by Barras [15] has also been calculated to compare both theoretical results. Finally, both results have been evaluated with the physical measurement for Bangladeshi inland ships.

\section{Brief Description Of Eedi By Imo}

EEDI in its simplest form can be expressed as follows [17]: 


$$
\begin{aligned}
& \mathrm{EEDI}=\frac{\mathrm{CO}_{2} \text { Emission }}{\text { Transport Work }} \\
& =\frac{\text { Power } \times \text { Specific Fuel Consumption } \times \mathrm{CO}_{2} \text { Conversion factor }}{\text { Factors } \times \text { Capacity } \times \text { Speed }} \\
& \left(\prod_{j=1}^{n} f_{j}\right)\left(\sum P_{M E(i)} \underset{i=1}{n M E} C_{F M E(i)} \times S F C_{M E(i)}\right)+\left(P_{A E} \times C_{F A E} \times S F C_{A E}\right)+\left(\prod_{j=1}^{n} f_{j} \sum_{i=1}^{n P T 1} P_{P T I(i)} \times C_{F A E} \times S F C_{A E}\right)- \\
& \left(\sum_{\mathrm{j}=1}^{\mathrm{neff}} \mathrm{f}_{\mathrm{eff}(\mathrm{i})} \times \mathrm{P}_{\mathrm{AEeff(i)}} \times \mathrm{C}_{\mathrm{FAE}} \times \mathrm{SFC}_{\mathrm{AE}}\right)- \\
& \left(\sum_{i=1}^{n e f f} f_{\text {eff(i) }} \times P_{\text {eff(i) }} \times C_{F M E} \times S C_{M E}\right) \\
& f_{i} X_{c} \mathrm{Xf}_{1} X f_{W} X \text { Capacity } X V_{R E F}
\end{aligned}
$$

Equation 1 of EEDI contains different constants and coefficients. The definition and meaning of those are described in IMO MEPC resolution, as shown in following Table 1 [17]: 


\section{Table 1}

Description of different parameters of EEDI by IMO

\begin{tabular}{|c|c|}
\hline Parameter & Description \\
\hline $\mathrm{P}_{\mathrm{ME}}$ & $75 \%$ of the main engine MCR (Maximum Continuous Rating) in kW \\
\hline $\mathrm{C}_{\mathrm{FME}}$ & $\begin{array}{l}\text { The non-dimensional conversion factor for the main engine between fuel consumption and } \\
\mathrm{CO}_{2} \text { emission }\end{array}$ \\
\hline $\mathrm{SFC}_{\mathrm{ME}}$ & Certified Specific Fuel Consumption of the main engine in $\mathrm{g} / \mathrm{kWh}$ \\
\hline$P_{A E}$ & Auxiliary Engine Power \\
\hline $\mathrm{C}_{\mathrm{FAE}}$ & $\begin{array}{l}\text { The non-dimensional conversion factor for auxiliary engine between fuel consumption and } \\
\mathrm{CO}_{2} \text { emission }\end{array}$ \\
\hline $\mathrm{SFC}_{\mathrm{AE}}$ & Certified Specific Fuel Consumption of the main engine in $\mathrm{g} / \mathrm{kWh}$ \\
\hline $\mathrm{P}_{\mathrm{PT}(\mathrm{i})}$ & $75 \%$ of rated power consumption of shaft motor \\
\hline$f_{\text {eff(i) }}$ & Availability factor of innovative energy efficiency technology \\
\hline$P_{\text {AEeff(i) }}$ & Auxiliary power reduction due to innovative electrical energy-efficient technology \\
\hline$P_{\text {eff(i) }}$ & $\begin{array}{l}\text { The output of innovative mechanical energy-efficient technology for propulsion at } 75 \% \\
\text { main engine power }\end{array}$ \\
\hline$f_{j}$ & $\begin{array}{l}\text { Correction factor to account for ship specific design elements. (E.g. ice-classed ships, } \\
\text { shuttle tankers) }\end{array}$ \\
\hline$f_{i}$ & $\begin{array}{l}\text { Correction factor to account for ship specific design elements. (E.g. ice-classed ships, } \\
\text { shuttle tankers) }\end{array}$ \\
\hline $\mathrm{f}_{\mathrm{C}}$ & Cubic capacity correction factor (for chemical tankers and gas carriers) \\
\hline$f_{I}$ & $\begin{array}{l}\text { The factor for general cargo ships equipped with cranes and other cargo related gear to } \\
\text { compensate for a loss of deadweight of the ship }\end{array}$ \\
\hline Capacity & 1. For Passenger Vessel: Gross Tonnage (GT). \\
\hline & $\begin{array}{l}\text { 2. For Cargo and Oil Tanker: Computed as a function of Deadweight as indicated in } 2.3 \text { and } \\
2.4 \text { of MEPC 245(66) (MEPC 245(66), 2014) "2014 Guidelines on the calculation of the } \\
\text { Attained EEDI for new ships" }\end{array}$ \\
\hline$f_{w}$ & $\begin{array}{l}\text { Non-dimensional coefficient indicating the decrease of speed in representative sea } \\
\text { condition of wave height, wave frequency \& wind speed }\end{array}$ \\
\hline $\mathrm{V}_{\text {ref }}$ & Ship speed in nautical miles per hour at $P_{M E}$ \\
\hline \multicolumn{2}{|c|}{$\begin{array}{l}\text { *Material from the IMO website www.imo.org is reproduced with the permission of the International } \\
\text { Maritime Organization (IMO), which does not accept responsibility for the correctness of the material as } \\
\text { reproduced: in case of doubt, IMO's authentic text shall prevail. Readers should check with their national } \\
\text { maritime Administration for any further amendments or the latest advice. International Maritime } \\
\text { Organization, } 4 \text { Albert Embankment, London, SE1 7SR, United Kingdom. }\end{array}$} \\
\hline
\end{tabular}




\section{Methodology To Revise Eedi Parameters For Inland Ships Of Bangladesh}

The methodology for revising EEDI of IMO parameters to be useful for inland ships of Bangladesh will follow the similar procedure by Hasan and Karim (Hasan and Karim, 2019) and MEPC Resolution [17] by IMO. The major changes of the methodology followed by Hasan and Karim [7] are presented in Table 2. The methodology for fixing capacity based on cargo availability and carbon content of fuel remained the same as proposed by Hasan and Karim [7].

Table 2

Changes in methodology and reasons

\begin{tabular}{|llll|}
\hline Change & Previous methods & Proposed methods & Reason \\
\hline $\begin{array}{l}\text { Incorporation } \\
\text { of shallow } \\
\text { water effect }\end{array}$ & $\begin{array}{l}\text { Hasan and Karim [7] used } \\
\text { Schlichting's [8] and Barras } \\
{[15] \text { methods. }}\end{array}$ & $\begin{array}{l}\text { The physically measured } \\
\text { result compared with } \\
\text { Lackenby [11] and Barras } \\
\text { [15] methods }\end{array}$ & $\begin{array}{l}\text { Lackenby [11] is } \\
\text { approved by ITTC. Kept } \\
\text { Barras's [15] method for } \\
\text { comparison. }\end{array}$ \\
$\begin{array}{l}\text { Fixing the } \\
\text { maximum } \\
\text { continuous } \\
\text { rating (MCR) }\end{array}$ & $\begin{array}{l}\text { The engine output of the main } \\
\text { engine was calculated from } \\
\text { the Holtrop-Mennen methods } \\
{[18,19.20]}\end{array}$ & $\begin{array}{l}\text { Engine output of the main } \\
\text { engine was taken from the } \\
\text { Engine curve. }\end{array}$ & $\begin{array}{l}\text { Use of engine curve will } \\
\text { provide more accurate } \\
\text { information of MCR }\end{array}$ \\
\hline
\end{tabular}

\subsection{Theory of speed drop due to the shallow water effect}

Ships plying on shallow water can easily be affected by the limited draft due to the squat effect. The water velocity is accelerated around the hull as the draft limitation restricts the water flow. This increase in water velocity results in a higher drag and eventually reduces the ship's hull efficiency. After a certain speed of the vessel, this shallow water effect becomes very pronounced. Any ship (regardless of its size) navigating through restricted waterways is heavily affected by these hydrodynamic effects.

\subsubsection{International Towing Tank Conference (ITTC) guideline}

ITTC recommended in the 'Procedures and guidelines for preparation, conduct and analysis of speed/power trials'

[10] that, if the water depth is less than the larger of the values obtained from the following two formulae, shallow water correction may be applied:

$h=3 \sqrt{B . T_{M}}$ and $h=2.75 \frac{V_{S}^{2}}{g}$, Where,

h: Water depth in meter

B: Ship's breadth in meter

$\mathrm{T}_{\mathrm{M}}$ : Draught at midship in meter 
$\mathrm{V}_{\mathrm{S}}$ : Ship's speed in $\mathrm{m} / \mathrm{s}$

$\mathrm{g}$ : Acceleration of gravity in $\mathrm{m} / \mathrm{s}^{2}$

If the above conditions are satisfied and the effect of shallow water on a ship's speed needs to be predicted, ITTC recommended the Lackenby method [11] or the Raven Shallow Water Correction Method [12]. This method does not provide any formulation, rather it is a procedure for a series of tests, which starts with CFD analysis. Later, this analysis is validated with model test and trial data. In practice, this is a very accurate process, but not a generalized process. In addition to that, the builder, owner, and verifier must agree upon this process, as stated in the ITTC [10] guideline. On the other hand, the Lackenby method [11] provides simple formulas and guidelines which are very handy. For this reason, Lackenby's [11] method is considered in this study.

\subsubsection{Ship speed loss prediction (Lackenby's method)}

The shallow-water correction method most often used is that of Lackenby [11]. It modifies the speed-power curve by correcting the measured speed, assuming unchanged power. Lackenby [11] extended Schlichting's [8] diagrams towards smaller effects and has cast it into a simpler form. This speed correction follows from:

$$
\frac{\partial \mathrm{V}}{\mathrm{V}}=0.1242\left(\frac{\mathrm{A}_{\mathrm{M}}}{\mathrm{H}^{2}}-0.05\right)+1-\sqrt{\tanh \left(\frac{\mathrm{gH}}{\mathrm{V}^{2}}\right)}, \text { Where, }
$$

$\mathrm{V}=$ Open water speed $(\mathrm{m} / \mathrm{s})$

$\partial \mathrm{V}=$ Reduced speed due to shallow water effect $(\mathrm{m} / \mathrm{s})$

$A_{M}=$ Midship Sectional Area under water $\left(m^{2}\right)$

$\mathrm{H}=$ Water depth $(\mathrm{m})$

$\mathrm{g}=$ Gravitational Force $\left(\mathrm{m} / \mathrm{s}^{2}\right)$

\subsubsection{Ship speed loss prediction (Barras method)}

The method as described by C. B. Barrass [15] the speed losses are calculated in percentage at different Water depth $(\mathrm{H})$ /Ship's draft $(\mathrm{T})$ ratios. Barras proposed two different equations primarily to cover first a range of $\mathrm{H} / \mathrm{T}$ from 1.10 to 1.50 and secondly a range of $\mathrm{H} / \mathrm{T}$ values from 1.50 to 3.00 . The first range was selected because at this range the most dangerous situations occur, leading to possible groundings. The second range is lead to grounding at high speed, which is less probable. The equations produced by the author of this book were:

$\%$ loss in speed $=60-(25 \mathrm{XH} / \mathrm{T})$, for $\mathrm{H} / \mathrm{T}$ of $1.1-1.50$

\% loss in speed $=36-(9 \mathrm{X} \mathrm{H/T})$, for H/T of 1.5-3.00,

where, 
$\mathrm{H}=$ Water depth in meter

$\mathrm{T}=$ Draft of the ship in meter

\subsubsection{Assumptions on the considerations of the effects of confined waters on ship resistance}

In this research, the effect of the riverbank on the resistance has not been considered and assumed to have a negligible effect. As stated in the ITTC report [16] the influence of riverbank is negligible when the channel width (W) to the ship breadth (B) ratio is greater than 4 . Without any exception, the maximum breadth of the inland ship of Bangladesh is 14 meters. Only very few passenger ships have breadth larger than that. $A$ vessel with a 14-meter breadth when moves through a channel of width less than 56 meters, only then the river bank effect will increase the resistance. However, it is very unlikely in Bangladesh that, a vessel having a breadth of 14 meters, plys through a narrow channel of width less than 56 meters.

The water depth of a certain route is not uniform. For this reason, the effect of shallow water will not be uniform as well. This research relies on the river water depth data at certain points only, which are measured daily by different government organizations of Bangladesh. Therefore, in this research, the average speed as measured in a certain route has been considered as the gained speed after overcoming the average effect of shallow water. In addition to that, the measured highest speed in each case has been considered as the achieved speed without any effect of shallow water, because in these routes there may be certain regions where the depth of water may be quite high than the measured depth at different locations.

\subsection{Investigated results on shallow water effect for the Inland Ships of Bangladesh}

To find the actual shallow water effect on ship speed, ship speed at service condition was measured for 15 vessels (05 from general cargo ships, 05 from oil tankers and 05 from passenger ships). Android-based app (Speedometer GPS) was used to measure ship speed using satellite. The travelled routes were different and water depths were varied. For this reason, measured speed also varied for the same RPM of the engine. The average speed has been considered as the gained speed after the shallow water effect.

Tables 3 and 4 present the investigated results of the 05 general cargo ships. In Table 3, investigated ship particulars, travelled route through the inland waterways of Bangladesh, travelled distance and water depths at different points are shown. The water levels of the selected river routes in Table 3 were found from the Bangladesh Inland Water Transport Authority [21], data from the 'Flood Forecasting \& Warning Centre' of the Bangladesh Water Development Board [22] and data from Chittagong Port Authority. Table 4 presents the speed measured for investigated ships at different locations. Measured top speed in each case has been considered as the achieved speed without any effect of shallow water. Since the measured speed drop due to the shallow water effect was not uniform, it has been presented in a range. To compare the theoretical speed, drop due to the shallow water effect, the same effect has been calculated by the methods explained by Schlicting [8], Lackenby [11] and Barras [15]. The deviations of calculated results from investigated results by those methods have been presented in Fig. 1. In a similar process, as explained above, 05 inland oil tankers 
and passenger ships of Bangladesh have been investigated and presented in Tables 5, 6 and Fig. 2 (for oil tankers) and 7, 8 and Fig. 3 (for passenger ships). 
Table 3

Investigated cargo ship's particulars, route, water depth

\begin{tabular}{|c|c|c|c|c|}
\hline $\begin{array}{l}\text { Ship's Dimension } \\
\text { (m) }\end{array}$ & Travelled Route & $\begin{array}{l}\text { Distance } \\
(\mathrm{km})\end{array}$ & $\begin{array}{l}\text { Water depth } \\
\text { (m) }\end{array}$ & $\begin{array}{l}\text { Average } \\
\text { water depth } \\
\text { (m) }\end{array}$ \\
\hline $\begin{array}{l}\text { G.C-1: LXBXT = } \\
47.24 X 07.95 X 2.55\end{array}$ & Dhaka to Chandpur & 68.22 & $\begin{array}{l}\text { 1. Milbarak, Dhaka, } \\
\text { Buriganga River: } 4.10 \mathrm{~m} \\
\text { 2. Mirkadim, Dhaleshwari } \\
\text { River: } 3.50 \mathrm{~m} \\
\text { 3. Char Ramdaspur, } \\
\text { Meghna River: } 4.05 \mathrm{~m}\end{array}$ & 3.88 \\
\hline $\begin{array}{l}\text { G.C-2: } \text { LXBXT= } \\
63.00 \times 11.60 \times 3.00\end{array}$ & $\begin{array}{l}\text { Meghnaghat, } \\
\text { Naryanganj to } \\
\text { Chittagong }\end{array}$ & 273.89 & $\begin{array}{l}\text { 1. Gazaria, Munshiganj, } \\
\text { Meghna River: } 4.90 \mathrm{~m} \\
\text { 2. Char Ramdaspur, } \\
\text { Meghna River: } 4.50 \mathrm{~m} \\
\text { 3. Chittagong, Karnaphuly } \\
\text { River: } 5.03 \mathrm{~m}\end{array}$ & 4.81 \\
\hline $\begin{array}{l}\text { G.C-3: LXBXT = } \\
66.00 \times 10.98 \times 3.00\end{array}$ & $\begin{array}{l}\text { Rupshi, Narayanganj to } \\
\text { Chittagong }\end{array}$ & 275.75 & $\begin{array}{l}\text { 1. Narayanganj, } \\
\text { Shitalakhya River: } 4.6 \mathrm{~m} \\
\text { 2. Mirkadim, Dhaleshwari } \\
\text { River: } 3.60 \mathrm{~m} \\
\text { 3. Char Ramdaspur, } \\
\text { Meghna River: } 3.77 \mathrm{~m} \\
\text { 4. Chittagong, Karnaphuly } \\
\text { River: } 4.39 \mathrm{~m}\end{array}$ & 4.09 \\
\hline $\begin{array}{l}\text { G.C-4: LXBXT }= \\
43.76 X 7.77 X 2.29\end{array}$ & $\begin{array}{l}\text { Fatullah, Narayanganj } \\
\text { to Baghabari }\end{array}$ & 189.86 & $\begin{array}{l}\text { 1. Fatullah, Buriganga } \\
\text { River: } 4.10 \mathrm{~m} \\
\text { 2. Mirkadim, Dhaleshwari } \\
\text { River: } 5.10 \mathrm{~m} \\
\text { 3. Char Ramdaspur, } \\
\text { Meghna River: } 4.050 \mathrm{~m} \\
\text { 4. Bhagyakul, Munshiganj, } \\
\text { Padma River: } 4.30 \mathrm{~m} \\
\text { 5. Aricha, Manikganj, } \\
\text { Jamuna river: } 7.25 \mathrm{~m} \\
\text { 6. Baghabari, Sirajganj, } \\
\text { Jamuna River: } 3.90 \mathrm{~m}\end{array}$ & 4.78 \\
\hline
\end{tabular}




\begin{tabular}{|lllll|}
\hline $\begin{array}{l}\text { Ship's Dimension } \\
(\mathbf{m})\end{array}$ & Travelled Route & $\begin{array}{l}\text { Distance } \\
(\mathbf{k m})\end{array}$ & $\begin{array}{l}\text { Water depth } \\
(\mathbf{m})\end{array}$ & $\begin{array}{l}\text { Average } \\
\text { water depth } \\
(\mathbf{m})\end{array}$ \\
\hline G.C-5: LXBXT $=$ & $\begin{array}{l}\text { Meghnaghat, } \\
\text { Nataryanganj to } \\
\text { Chittagong }\end{array}$ & 273.89 & $\begin{array}{l}\text { 1. Gazaria, Munshiganj, } \\
\text { Meghna River: } 5.45 \mathrm{~m}\end{array}$ & 4.97 \\
& & & $\begin{array}{l}\text { 2. Chandpur, Meghna } \\
\text { River: } 4.43 \mathrm{~m}\end{array}$ & \\
& & & $\begin{array}{l}\text { 3. Chittagong, Karnaphuly } \\
\text { River: } 4.98 \mathrm{~m}\end{array}$ & \\
\hline
\end{tabular}

Table 4

Investigated cargo ship's speeds during the investigation

\begin{tabular}{|lllllll|}
\hline $\begin{array}{l}\text { Ship } \\
\text { ID (m) }\end{array}$ & $\begin{array}{l}\text { Service } \\
\text { speed (Knot) }\end{array}$ & $\begin{array}{l}\text { Shallow water } \\
\text { speed (Knot) }\end{array}$ & $\begin{array}{l}\text { Actual shallow } \\
\text { water effect }\end{array}$ & $\begin{array}{l}\text { Lackenby } \\
\text { (1963) }\end{array}$ & $\begin{array}{l}\text { Barras } \\
\text { (2004) }\end{array}$ & $\begin{array}{l}\text { Schlicting } \\
\text { (1934) }\end{array}$ \\
\hline G.C-1 & 9.5 & $7.50-8.00$ & $\begin{array}{l}16 \%-21 \% \\
\text { (Average } 18.50 \%)\end{array}$ & $19.93 \%$ & $22.31 \%$ & $4.04 \%$ \\
\hline G.C-2 & 10.0 & $7.50-8.50$ & $\begin{array}{l}15 \%-25 \% \text { (Average } \\
\text { 20\%) }\end{array}$ & $20.61 \%$ & $21.57 \%$ & $2.79 \%$ \\
\hline G.C-3 & 10.5 & $7.50-8.00$ & $\begin{array}{l}24 \%-29 \%(\text { Average } \\
\text { 26.50\%) }\end{array}$ & $29.47 \%$ & $25.92 \%$ & $6.20 \%$ \\
\hline G.C-4 & 9.5 & $8.00-9.00$ & $\begin{array}{l}5 \%-16 \% \text { (Average } \\
10.50 \%)\end{array}$ & $10.83 \%$ & $17.21 \%$ & $1.95 \%$ \\
\hline G.C-5 & 10.5 & $7.50-8.50$ & $\begin{array}{l}19 \%-29 \% \text { (Average } \\
\text { 24\%) }\end{array}$ & $28.73 \%$ & $28.94 \%$ & $3.47 \%$ \\
\hline
\end{tabular}


Table 5

Investigated oil tanker's particulars, route, water depth and speeds during the investigation

\begin{tabular}{|c|c|c|c|c|}
\hline $\begin{array}{l}\text { Ship's Dimension } \\
\text { (m) }\end{array}$ & Travelled Route & $\begin{array}{l}\text { Distance } \\
(\mathrm{km})\end{array}$ & $\begin{array}{l}\text { Water depth } \\
\text { (m) }\end{array}$ & $\begin{array}{l}\text { Average } \\
\text { water depth } \\
\text { (m) }\end{array}$ \\
\hline \multirow{6}{*}{$\begin{array}{l}\text { O.T-1, LXBXT }= \\
50.67 X 10.68 \times 1.80\end{array}$} & \multirow[t]{6}{*}{$\begin{array}{l}\text { Fatullah, Narayanganj } \\
\text { to Baghabari }\end{array}$} & \multirow[t]{6}{*}{189.86} & $\begin{array}{l}\text { 1. Fatullah, Narayanganj, } \\
\text { Buriganga River: } 3.85 \mathrm{~m}\end{array}$ & \multirow[t]{6}{*}{4.02} \\
\hline & & & $\begin{array}{l}\text { 2. Mirkadim, Dhaleshwari } \\
\text { River: } 5.10 \mathrm{~m}\end{array}$ & \\
\hline & & & $\begin{array}{l}\text { 3. Char Ramdaspur, } \\
\text { Meghna River: } 3.35 \mathrm{~m}\end{array}$ & \\
\hline & & & $\begin{array}{l}\text { 4. Bhagyakul, Munshiganj, } \\
\text { Padma River: } 3.90 \mathrm{~m}\end{array}$ & \\
\hline & & & $\begin{array}{l}\text { 5. Arihca, Manikganj, } \\
\text { Jamuna river: } 5.00 \mathrm{~m}\end{array}$ & \\
\hline & & & $\begin{array}{l}\text { 6. Baghabari, Sirajganj, } \\
\text { Jamuna River: } 2.90 \mathrm{~m}\end{array}$ & \\
\hline \multirow{3}{*}{$\begin{array}{l}\text { O.T-2, LXBXT= } \\
57.24 \\
\text { X10.00X1.80 }\end{array}$} & \multirow[t]{3}{*}{ Dhaka to Chandpur } & \multirow[t]{3}{*}{68.22} & $\begin{array}{l}\text { 1. Milbarak, Dhaka, } \\
\text { Buriqanqa River: } 3.90 \text { m }\end{array}$ & \multirow[t]{3}{*}{3.75} \\
\hline & & & $\begin{array}{l}\text { 2. Mirkadim, Dhaleshwari } \\
\text { River: } 3.50 \mathrm{~m}\end{array}$ & \\
\hline & & & $\begin{array}{l}\text { 3. Char Ramdaspur, } \\
\text { Meghna River: } 3.84 \mathrm{~m}\end{array}$ & \\
\hline \multirow{3}{*}{$\begin{array}{l}\text { O.T-3, LXBXT }= \\
70.80 \times 12.50 \times 4.00\end{array}$} & \multirow{3}{*}{$\begin{array}{l}\text { Meghnaghat, } \\
\text { Naryanganj to } \\
\text { Chittagong }\end{array}$} & \multirow[t]{3}{*}{273.89} & $\begin{array}{l}\text { 1. Gazaria, Munshiganj, } \\
\text { Meghna River: } 5.00 \text { m }\end{array}$ & \multirow[t]{3}{*}{4.93} \\
\hline & & & $\begin{array}{l}\text { 2. Chandpur, Meghna River: } \\
4.80 \mathrm{~m}\end{array}$ & \\
\hline & & & $\begin{array}{l}\text { 3. Sadarghat, Karnaphuly } \\
\text { River: } 5.00 \mathrm{~m}\end{array}$ & \\
\hline \multirow[t]{4}{*}{$\begin{array}{l}\text { OT-4, LXBXT = } \\
53.00 \times 11 X 1.8\end{array}$} & \multirow[t]{4}{*}{$\begin{array}{l}\text { Godnail, Narayanganj } \\
\text { to Barishal }\end{array}$} & \multirow[t]{4}{*}{134.56} & $\begin{array}{l}\text { 1. Godnail, Narayanganj, } \\
\text { Shitalkhya River: } 3.79 \mathrm{~m}\end{array}$ & \multirow[t]{4}{*}{3.23} \\
\hline & & & $\begin{array}{l}\text { 2. Munshiganj, Dhaleshwari } \\
\text { River: } 3.50 \mathrm{~m}\end{array}$ & \\
\hline & & & $\begin{array}{l}\text { 3. Char Ramdaspur, } \\
\text { Meghna River: } 3.49 \mathrm{~m}\end{array}$ & \\
\hline & & & $\begin{array}{l}\text { 4. Barishal, Kirtankhola } \\
\text { River: } 2.15 \mathrm{~m}\end{array}$ & \\
\hline
\end{tabular}




\begin{tabular}{|c|c|c|c|c|}
\hline $\begin{array}{l}\text { Ship's Dimension } \\
\text { (m) }\end{array}$ & Travelled Route & $\begin{array}{l}\text { Distance } \\
(\mathrm{km})\end{array}$ & $\begin{array}{l}\text { Water depth } \\
\text { (m) }\end{array}$ & $\begin{array}{l}\text { Average } \\
\text { water depth } \\
\text { (m) }\end{array}$ \\
\hline \multirow[t]{4}{*}{$\begin{array}{l}\text { OT-5, } \\
49.50 \times 10.00 \times 2.00\end{array}$} & Dhaka to Bhairab & 110.81 & $\begin{array}{l}\text { 1. Milbarak, Dhaka, } \\
\text { Buriganga River: } 4.00 \mathrm{~m}\end{array}$ & 3.50 \\
\hline & & & $\begin{array}{l}\text { 2. Munshiganj, Dhaleshwari } \\
\text { River: } 3.80 \mathrm{~m}\end{array}$ & \\
\hline & & & $\begin{array}{l}\text { 3. Gazaria, Munshiganj, } \\
\text { Meghna River: } 2.60 \mathrm{~m}\end{array}$ & \\
\hline & & & $\begin{array}{l}\text { 4. Ashuganj, Meghna River: } \\
3.60 \mathrm{~m}\end{array}$ & \\
\hline
\end{tabular}

Table 6

Investigated oil tanker's speeds during the investigation

\begin{tabular}{|lllllll|}
\hline $\begin{array}{l}\text { Ship } \\
\text { ID }(\mathrm{m})\end{array}$ & $\begin{array}{l}\text { Service } \\
\text { speed (Knot) }\end{array}$ & $\begin{array}{l}\text { Shallow water } \\
\text { speed (Knot) }\end{array}$ & $\begin{array}{l}\text { Actual shallow } \\
\text { water effect }\end{array}$ & $\begin{array}{l}\text { Lackenby } \\
\text { (1963) }\end{array}$ & $\begin{array}{l}\text { Barras } \\
(\mathbf{2 0 0 4})\end{array}$ & $\begin{array}{l}\text { Schlicting } \\
\text { (1934) }\end{array}$ \\
\hline O.T-1 & 9.50 & $7.50-8.00$ & $\begin{array}{l}16 \%-21 \% \\
(\text { Average 18.50\%) }\end{array}$ & $17.62 \%$ & $15.90 \%$ & $3.61 \%$ \\
\hline O.T-2 & 8.50 & $7.00-7.50$ & $\begin{array}{l}12 \%-18 \% \\
(\text { Average 15\%) }\end{array}$ & $17.33 \%$ & $17.25 \%$ & $2.11 \%$ \\
\hline O.T-3 & 10.50 & $7.50-8.50$ & $\begin{array}{l}19 \%-29 \% \\
(\text { Average 24\%) }\end{array}$ & $28.30 \%$ & $29.19 \%$ & $3.57 \%$ \\
\hline OT-4 & 9.50 & $7.00-7.50$ & $\begin{array}{l}12 \%-24 \% \\
\text { (Average 18\%) }\end{array}$ & $29.55 \%$ & $19.85 \%$ & $6.81 \%$ \\
\hline OT-5 & 8.50 & $6.50-7.00$ & $\begin{array}{l}18 \%-24 \% \\
(\text { Average 21\%) }\end{array}$ & $22.20 \%$ & $20.25 \%$ & $2.72 \%$ \\
\hline
\end{tabular}


Table 7

Investigated passenger vessel's particulars, route, water depth and speeds during the investigation

\begin{tabular}{|c|c|c|c|c|}
\hline $\begin{array}{l}\text { Ship's Dimension } \\
\text { (m) }\end{array}$ & Travelled Route & $\begin{array}{l}\text { Distance } \\
(\mathrm{km})\end{array}$ & $\begin{array}{l}\text { Water depth } \\
\text { (m) }\end{array}$ & $\begin{array}{l}\text { Average water } \\
\text { depth }(\mathrm{m})\end{array}$ \\
\hline \multirow{3}{*}{$\begin{array}{l}\text { P.V-1, LXBXT }= \\
48.56 \times 8.75 X 1.62\end{array}$} & \multirow{3}{*}{$\begin{array}{l}\text { Dhaka to Sureswar, } \\
\text { Shariyatpur }\end{array}$} & \multirow[t]{3}{*}{85.82} & $\begin{array}{l}\text { 1. Milbarak, Dhaka, } \\
\text { Buriganga River } 390 \mathrm{~m}\end{array}$ & \multirow[t]{3}{*}{3.38} \\
\hline & & & $\begin{array}{l}\text { 2. Munshiganj, } \\
\text { Dhaleshwari River: } 3.40 \mathrm{~m}\end{array}$ & \\
\hline & & & $\begin{array}{l}\text { 3. Sureswar, Padma River: } \\
2.75 \mathrm{~m}\end{array}$ & \\
\hline \multirow{4}{*}{$\begin{array}{l}\text { P.V-2, LXBXT }= \\
45.95 \times 09.15 \times 1.40\end{array}$} & \multirow[t]{4}{*}{$\begin{array}{l}\text { Dhaka to } \\
\text { Tushkhali, Pirojpur }\end{array}$} & \multirow[t]{4}{*}{249.89} & $\begin{array}{l}\text { 1. Milbarak, Dhaka, } \\
\text { Buriganga River: } 4.00 \mathrm{~m}\end{array}$ & \multirow[t]{4}{*}{3.38} \\
\hline & & & $\begin{array}{l}\text { 2. Munshiganj, } \\
\text { Dhaleshwari River: } 3.40 \mathrm{~m}\end{array}$ & \\
\hline & & & $\begin{array}{l}\text { 3. Char Ramdaspur, } \\
\text { Meghna River: } 3.88 \mathrm{~m}\end{array}$ & \\
\hline & & & $\begin{array}{l}\text { 4. Barishal, Kirtankhola } \\
\text { River: } 2.23 \mathrm{~m}\end{array}$ & \\
\hline \multirow{3}{*}{$\begin{array}{l}\text { P.V-3, LXBXT }= \\
67.47 X 10.98 \times 1.70\end{array}$} & \multirow[t]{3}{*}{ Dhaka to Chandpur } & \multirow[t]{3}{*}{68.22} & $\begin{array}{l}\text { 1. Milbarak, Dhaka, } \\
\text { Buriganga River: } 4.0 \mathrm{~m}\end{array}$ & \multirow[t]{3}{*}{4.14} \\
\hline & & & $\begin{array}{l}\text { 2. Mirkadim, Dhaleshwari } \\
\text { River: } 4.42 \mathrm{~m}\end{array}$ & \\
\hline & & & $\begin{array}{l}\text { 3. Char Ramdaspur, } \\
\text { Meghna River: } 4.0 \mathrm{~m}\end{array}$ & \\
\hline \multirow{4}{*}{$\begin{array}{l}\text { P.V-4, LXBXT= } \\
54.29 \times 10.84 X 1.60\end{array}$} & \multirow[t]{4}{*}{$\begin{array}{l}\text { Dhaka to } \\
\text { Patuakhali }\end{array}$} & \multirow[t]{4}{*}{197.10} & $\begin{array}{l}\text { 1. Milbarak, Dhaka, } \\
\text { Buriganga River: } 4.00 \mathrm{~m}\end{array}$ & \multirow[t]{4}{*}{3.48} \\
\hline & & & $\begin{array}{l}\text { 2. Munshiganj, } \\
\text { Dhaleshwari River: } 3.20 \mathrm{~m}\end{array}$ & \\
\hline & & & $\begin{array}{l}\text { 3. Char Ramdaspur, } \\
\text { Meghna River: } 3.80 \mathrm{~m}\end{array}$ & \\
\hline & & & $\begin{array}{l}\text { 4. Patuakhali, Patuakhali } \\
\text { River: } 2.93 \mathrm{~m}\end{array}$ & \\
\hline \multirow[t]{4}{*}{$\begin{array}{l}\text { P.V-5, LXBXT = } \\
\text { 85.34X13.57X1.80 }\end{array}$} & \multirow[t]{4}{*}{ Dhaka to Barishal } & \multirow[t]{4}{*}{147.61} & $\begin{array}{l}\text { 1. Milbarak, Dhaka, } \\
\text { Buriganga River: } 4.00 \mathrm{~m}\end{array}$ & \multirow[t]{4}{*}{3.96} \\
\hline & & & $\begin{array}{l}\text { 2. Munshiganj, } \\
\text { Dhaleshwari River: } 3.40 \mathrm{~m}\end{array}$ & \\
\hline & & & $\begin{array}{l}\text { 3. Char Ramdaspur, } \\
\text { Meghna River: } 4.0 \mathrm{~m}\end{array}$ & \\
\hline & & & $\begin{array}{l}\text { 4. Barishal, Kirtankhola } \\
\text { River: } 4.45 \mathrm{~m}\end{array}$ & \\
\hline
\end{tabular}


Table 8

Investigated passenger vessel's speeds during the investigation

\begin{tabular}{|lllllll|}
\hline $\begin{array}{l}\text { Ship } \\
\text { ID (m) }\end{array}$ & $\begin{array}{l}\text { Service } \\
\text { speed (Knot) }\end{array}$ & $\begin{array}{l}\text { Shallow water } \\
\text { speed (Knot) }\end{array}$ & $\begin{array}{l}\text { Actual shallow } \\
\text { water effect }\end{array}$ & $\begin{array}{l}\text { Lackenby } \\
\text { (1963) }\end{array}$ & $\begin{array}{l}\text { Barras } \\
\text { (2004) }\end{array}$ & $\begin{array}{l}\text { Schlicting } \\
\text { (1934) }\end{array}$ \\
\hline P.V-1 & 11.5 & $8.50-9.50$ & $\begin{array}{l}17 \%-26 \% \\
\text { (Average } 21.50 \%)\end{array}$ & $28.56 \%$ & $17.22 \%$ & $14.05 \%$ \\
\hline P.V-2 & 12.0 & $8.50-9.50$ & $\begin{array}{l}21 \%-29 \% \\
\text { (Average 25\%) }\end{array}$ & $29.16 \%$ & $14.27 \%$ & $16.25 \%$ \\
\hline P.V-3 & 13.5 & $10.50-11.00$ & $\begin{array}{l}18 \%-22 \% \\
\text { (Average 20\%) }\end{array}$ & $29.83 \%$ & $14.08 \%$ & $17.12 \%$ \\
\hline P.V-4 & 10.0 & $7.50-8.50$ & $\begin{array}{l}15 \%-25 \% \\
\text { (Average 20\%) }\end{array}$ & $24.16 \%$ & $16.43 \%$ & $7.31 \%$ \\
\hline P.V-5 & 12.5 & $10.50-11.00$ & $\begin{array}{l}12 \%-16 \% \\
\text { (Average 14\%) }\end{array}$ & & & \\
\hline
\end{tabular}

Table 9 summarizes the average speed drops in the shallow water of those investigated ships. In addition to that, the average of theoretical results by Schlicting [8], Lackenby [11] and Barras [15] and average deviation from the investigated results for each type of ship are also presented.

Table 9

Average shallow water effects by investigations and theoretical methods

\begin{tabular}{|llllllll|}
\hline $\begin{array}{l}\text { Type of } \\
\text { investigated } \\
\text { ships }\end{array}$ & $\begin{array}{l}\text { Average } \\
\text { speed drop } \\
\text { (Investigated) }\end{array}$ & $\begin{array}{l}\text { Average speed drop by different methods and deviation from the } \\
\text { investigation }\end{array}$ & $\begin{array}{l}\text { Lackenby } \\
\text { Leviation }\end{array}$ & $\begin{array}{l}\text { Barras } \\
\text { (1963) }\end{array}$ & $\begin{array}{l}\text { Deviation } \\
\text { (2004) }\end{array}$ & $\begin{array}{l}\text { Schlicting } \\
\text { (1) }\end{array}$ & $\begin{array}{l}\text { Deviation } \\
\text { (19) }\end{array}$ \\
\hline Cargo Ships & $19.90 \%$ & $21.91 \%$ & $10.10 \%$ & $23.19 \%$ & $16.53 \%$ & $3.69 \%$ & $-81.46 \%$ \\
\hline Oil Tankers & $19.30 \%$ & $23 \%$ & $19.17 \%$ & $20.49 \%$ & $6.17 \%$ & $3.76 \%$ & $-80.52 \%$ \\
\hline $\begin{array}{l}\text { Passenger } \\
\text { Ships }\end{array}$ & $20.10 \%$ & $28.91 \%$ & $43.83 \%$ & $15.64 \%$ & $-22.19 \%$ & $13.80 \%$ & $-31.34 \%$ \\
\hline
\end{tabular}

\subsection{Fixing the main engine $M C R$ and $P_{M E}$ considering shallow water effect.}

A previous paper by Hasan and Karim [7] has suggested 60\% MCR based on the average of verified ship data. As mentioned in Table 2, the ship data verification process was based on the Holtrop-Mennen methods $[18,19,20]$, which requires too many ships data/information. Unavailable ship data/information was assumed in most cases by Hasan and Karim [7].

In this study, MCR was considered from the practically measured 15 ships that were used to identify the average shallow water effect. During the physical investigation, the main engine RPM was measured when the ship started to move at continuous RPM for the maximum possible time. A digital tachometer was used for RPM measurement. The main engine load at the MCR was found from the Engine performance curve. 
Following Tables 10, 11 and 12 present the onboard measured RPM data and corresponding main engine loads for Inland General Cargo Ships, Oil Tankers and Passenger Ships, chronologically.

Table 10

Main engine rpm and engine load at actual for 05 Inland Cargo Vessels of Bangladesh

\begin{tabular}{|llll|}
\hline Ship's ID & Main Engine Power (HP) & Engine RPM at service speed & Main Engine Load (Average) \\
\hline G.C-1 & $350 \times 1$ & 1395 & $78.00 \%$ \\
\hline G.C-2 & $350 \times 2$ & 1402 & $80.00 \%$ \\
\hline G.C-3 & $350 \times 2$ & 1275 & $61.00 \%$ \\
\hline G.C-4 & $350 \times 1$ & 1380 & $76.00 \%$ \\
\hline G.C-5 & $720 \times 2$ & 1044 & $64.50 \%$ \\
\hline
\end{tabular}

Table 11

Main engine rpm and engine load at actual for 05 Inland Oil Tankers of Bangladesh

\begin{tabular}{|llll|}
\hline Ship's ID & Main Engine Power (HP) & Engine RPM at service speed & Main Engine Load (Average) \\
\hline O.T-1 & $350 \times 2$ & 1320 & $67.00 \%$ \\
\hline O.T-2 & $300 \times 2$ & 1320 & $65.00 \%$ \\
\hline O.T-3 & $818 \times 2$ & 1256 & $77 \%$ \\
\hline OT-4 & $300 \times 2$ & 1290 & $60 \%$ \\
\hline OT-5 & $350 \times 1$ & 1395 & $76 \%$ \\
\hline
\end{tabular}

Table 12

Main engine rpm and engine load at actual for 05 Inland Passenger Ships of Bangladesh

\begin{tabular}{|llll|}
\hline Ship's ID & Main Engine Power (HP) & Engine RPM at service speed & Main Engine Load (Average) \\
\hline P.V-1 & $350 \times 2$ & 1420 & $82 \%$ \\
\hline P.V-2 & $300 \times 2$ & 1620 & $70 \%$ \\
\hline P.V-3 & $750 \times 2$ & 1269 & $82 \%$ \\
\hline P.V-4 & $350 \times 2$ & 1395 & $78 \%$ \\
\hline P.V-5 & $1000 \times 2$ & 846 & $90 \%$ \\
\hline
\end{tabular}

The average main engine loads of investigated ships are
a. $71.90 \%$ for General cargo ships
b. $69 \%$ for Oil Tankers
c. $80.40 \%$ for Passenger Ships 
Fixing 70\% MCR for General Cargo and Oil Tanker seems reasonable. For passenger ships, MCR can be $80 \%$, which is the average of the investigated ships' MCR.

\section{Result}

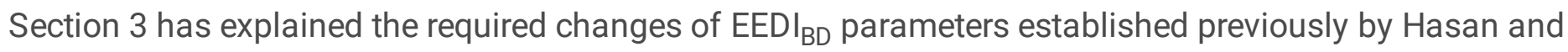
Karim [7]. Based on the new physical investigations, the changed values of those parameters have also been proposed. Following Table 13 summarizes those proposals.

Table 13

Comparison of the value of different EEDI parameters as defined by IMO and those for inland ships of Bangladesh.

\begin{tabular}{|c|c|c|}
\hline EEDI Parameter & $\begin{array}{l}\text { Defined by Hasan and Karim } \\
\text { [7] }\end{array}$ & $\begin{array}{l}\text { Revised value for the inland ship of } \\
\text { Bangladesh }\end{array}$ \\
\hline MCR & $60 \%$ & $\begin{array}{l}70 \% \text { for Cargo and Oil Tanker and } 80 \% \\
\text { for Passenger Ships }\end{array}$ \\
\hline$P_{M E}$ & $\begin{array}{l}60 \% \text { of the main engine MCR } \\
\text { in } \mathrm{kW}\end{array}$ & $\begin{array}{l}\text { Main Engine power at } 70 \% \text { MCR for } \\
\text { Cargo and Oil Tankers and } 80 \% \text { for the } \\
\text { Passenger Ships }\end{array}$ \\
\hline $\mathrm{V}_{\mathrm{REF}}$ & $\begin{array}{l}\text { Ship speed is at } P_{M E} \text { (at } 60 \% \\
\text { MCR) }\end{array}$ & $\begin{array}{l}\text { Ship speed at } \mathrm{P}_{\mathrm{ME}} \text {, incorporating the } \\
\text { average shallow water effect (at } 70 \% \\
\text { MCR for cargo and oil tanker and at } \\
80 \% \text { MCR for passenger ships) }\end{array}$ \\
\hline Capacity & $\begin{array}{l}85 \% \text { of the design dead } \\
\text { weight for Cargo and Oil } \\
\text { Tankers but } 100 \% \text { Gross } \\
\text { Tonnage (GT) for passenger } \\
\text { ships }\end{array}$ & $\begin{array}{l}\text { The proposal by Hasan and Karim [7] } \\
\text { was found reasonable. }\end{array}$ \\
\hline Carbon Content of Diesel oil & 0.76 & $\begin{array}{l}\text { The proposal by Hasan and Karim [7] } \\
\text { was found reasonable. }\end{array}$ \\
\hline $\begin{array}{l}\mathrm{C}_{\mathrm{F}} \text { (non-dimensional } \\
\text { conversion factor between } \\
\text { fuel consumption and } \mathrm{CO}_{2} \\
\text { emission based on carbon } \\
\text { content.) }\end{array}$ & $\begin{array}{l}\mathrm{C}_{\mathrm{F}} \text { : Carbon Content in the } \\
\text { fuel } \mathrm{X} \text { (Molecular weight of } \\
\mathrm{CO}_{2} / \text { Molecular weight of } \\
\text { Carbon) }=0.76 \times(44 / 12) \\
=2.787 \mathrm{gm} \mathrm{CO}_{2} / \mathrm{gm} \text { fuel }\end{array}$ & $\begin{array}{l}\text { The proposal by Hasan and Karim [7] } \\
\text { was found reasonable. }\end{array}$ \\
\hline
\end{tabular}

\subsection{Sample Calculation}

Based on the revised value, a good number of inland General Cargo, Oil Tanker and Passenger Ships of Bangladesh were taken into consideration to calculate $\mathrm{EEDI}_{\mathrm{BD}}$. Table 14 shows sample calculation using IMO defined EEDI formulation and using the revised EEDI parameters for Bangladesh (EEDI $\mathrm{BD})$. 
Table 14

Sample calculation of different values of EEDI for inland cargo ship of Bangladesh

\begin{tabular}{|c|c|c|c|}
\hline \multicolumn{4}{|c|}{ Vessel's Basic parameters: Length: 71.94 m, Breadth: 13 m, Draft: 4 m, Block Coefficient: 0.794} \\
\hline & $\begin{array}{l}\text { EEDI by } \\
\text { IMO }\end{array}$ & Previous EEDI $\mathrm{BD}_{\mathrm{B}}$ & Updated EEDI $\mathrm{BD}_{\mathrm{B}}$ \\
\hline Installed Engine Power (kW) & 1075 & 1075 & 1075 \\
\hline $\mathrm{P}_{\mathrm{ME}}(\mathrm{kW})$ & 806 & 644 & 756 \\
\hline MCR (\%) & $75 \%$ & $60 \%$ & $70 \%$ \\
\hline $\begin{array}{l}\text { Main Engine RPM at MCR (\% of the } \\
\text { maximum engine RPM) }\end{array}$ & $90 \%$ & $84.50 \%$ & $88.50 \%$ \\
\hline Open water speed at MCR (kW) & 10.50 & 10.00 & 10.40 \\
\hline River depth (m) & $\begin{array}{l}\text { Not } \\
\text { considered }\end{array}$ & 4.97 & 4.97 \\
\hline \multirow[t]{2}{*}{ Shallow water effect } & $\begin{array}{l}\text { Not } \\
\text { considered }\end{array}$ & $\begin{array}{l}4 \% \text { (Schlicting } \\
\text { (Schlichting, 1934) } \\
\text { method) }\end{array}$ & $\begin{array}{l}28.73 \% \text { (Lackenby } \\
\text { (Lackenby, 1963) } \\
\text { method) }\end{array}$ \\
\hline & & & $\begin{array}{l}\text { 28.94\% (Barras (Barrass, } \\
\text { 2004) method) }\end{array}$ \\
\hline $\mathrm{C}_{\mathrm{FME}}$ (Diesel oil) & 3.206 & 2.787 & 2.787 \\
\hline $\mathrm{SFC}_{\mathrm{ME}}(\mathrm{g} / \mathrm{kWhr})$ & 190 & 190 & 190 \\
\hline$P_{A E}(k W)$ & 53 & 53 & 53 \\
\hline $\mathrm{C}_{\mathrm{FAE}}$ (Diesel oil) & 3.206 & 2.787 & 2.787 \\
\hline $\mathrm{SFC}_{\mathrm{AE}}(\mathrm{g} / \mathrm{kWhr})$ & 200 & 200 & 200 \\
\hline$P_{P T(i)}, f_{\text {eff(i), }}, P_{A E \text { eff(i), }} P_{\text {eff(i) }}$ & 0 & 0 & 0 \\
\hline$f_{j}, f_{j}, f_{c}, f_{1}, f_{W}$ & 1 & 1 & 1 \\
\hline Capacity (Tonne) & 2200 & 1870 & 1870 \\
\hline $\mathrm{V}_{\mathrm{REF}}(\mathrm{knot})$ & 10.50 & 9.60 & $\begin{array}{l}7.48 \text { (Lackenby) } 7.46 \\
\text { (Barras) }\end{array}$ \\
\hline Index value (gram/kW.hr) & 22.75 & 19.84 & 22.15 \\
\hline
\end{tabular}

\section{Discussion}

The average actual shallow water effect varied from $19.30 \%-21.10 \%$ considering 5 measured ships of each type (total 15 ships). Since this effect mainly depends upon the clearance under the keel, different ship drafts will produce different amounts of effect in the same channel. Practically it is not possible to fix a single 
factor of speed deduction while considering the shallow water effect. Based on the actual measurement, a $20 \%$ speed drop can be considered due to the shallow water effect to establish EEDI $\mathrm{BD}_{\mathrm{BD}}$ baselines for inland general cargo, oil tanker and passenger ships of Bangladesh.

$\mathrm{EEDI}_{\mathrm{BD}}$ for any new inland Bangladeshi ship, the individual shallow water effect can be calculated theoretically at the design stage. The calculated values by Lakenby [11] and Barras [15] methods are nearer to the actual. However, for all 3 types of vessels, results calculated by Schlicting [8] are much lower than the investigated results. Therefore, both Lekenby [11] and Barras [15] methods can be used for new ships instead of Schlicting [8].

\section{Conclusion}

Although inland shipping accounts for only $9 \%$ of the total $\mathrm{CO}_{2}$ emissions of global shipping [3], attempts to reduce $\mathrm{CO}_{2}$ from its current level can be very important for individual countries from an economic and environmental perspective. Restrictions on inland navigation will vary from country to country because of the differences in geographical conditions. As a result, a generalized EEDI like for sea-going ships is not possible. This reanalysis is a step to modify EEDI formulation to be applicable for inland ships of Bangladesh.

As mentioned in Section 3.1.4 the effect of the width of narrow riverbanks on ship resistance has not been considered. The assumption is seemed fairly all right and explained in the same Section. However, for future research, these effects can be taken into consideration to justify the assumption.

\section{Declarations}

\section{Acknowledgements}

The authors acknowledge the Bangladesh University of Engineering and Technology (BUET) for all support to do this research.

\section{Author Contributions}

Conceptualization, S.M. Rashidul Hasan; Methodology, S. M. Rashidul Hasan; Software, S. M. Rashidul Hasan; Validation, S. M. Rashidul Hasan and Md. Mashud Karim.; Formal analysis, S. M. Rashidul Hasan.; Investigation, S. M. Rashidul Hasan, resources, S. M. Rashidul Hasan and Md. Mashud Karim; Writingoriginal draft preparation, S. M. Rashidul Hasan; Writing-review and editing, S. M. Rashidul Hasan and Md. Mashud Karim; Visualization, S. M. Rashidul Hasan.

\section{Funding}

This research is non-funded and does not have any financial interest.

\section{Availability of data and materials}

The data sets used and analyzed in the current study are available from the corresponding author on reasonable request. 


\section{Ethics approval and consent to participate}

Not applicable.

\section{Consent for publication}

Not applicable.

\section{Competing interests}

The authors declare that they have no competing interests.

\section{References}

1. MEPC 203 (62). Amendments to the Annex of the Protocol of 1997 To Amend the International Convention for the Prevention of Pollution from Ships, 1973, As Modified by the Protocol of 1978 Relating Thereto, Inclusion of regulations on energy efficiency for ships in MARPOL Annex VI, MEPC 62/24/Add.1, Annex 19, page 1, International Maritime Organization (IMO) (2011).

2. Bazari, Z., \& Longva, T. Assessment of IMO Mandated Energy Efficiency Measures for International Shipping- Estimated $\mathrm{CO}_{2}$ emissions reduction from introduction of mandatory technical and operational energy efficiency measures for ships. IMO, MEPC 63/INF.2 Project, Final Report (2011).

3. Naya, O., Bryan C., Biswajoy R., Xiaoli M., \& Rutherford D. Green House Gas Emissions from Global Shipping, 2013-2015. The International Council for Clean Transportation (ICCT) report (2017).

4. Simic, A. Energy Efficiency of Inland Waterway Self-Propelled Cargo Ships. International Conference on the Influence of EEDI on Ship Design, vol. 1, 25-30 (2014). ISBN: $1909024309,9781909024304$.

5. Khimich, V. L., Kuznetsov, Y. P., Bazhan, P. I., Soloviev, A. V., \& Khrunkov, S. N. About the indicator of energy efficiency of ships, Nizhny Novgorod State Technical University, Nizhny Novgorod State Technical University, IOP Conf. Series: Journal of Physics: Conf. Series 1177 (2019) 012021 (2019) DOI:10.1088/1742-6596/1177/1/012021

6. Karim, M. M., \& Hasan, S. M. R. Establishment of EEDI baseline for inland ship of Bangladesh. Journal of Procedia Engineering, Volume 194, 370-377 (2017) https://doi.org/10.1016/j.proeng.2017.08.159.

7. Hasan, S. M. R., \& Karim, M. M. Revised energy efficiency design index parameters for inland cargo ships of Bangladesh, Proc IMechE Part M: J Engineering for the Maritime Environment, Vol. 234(1) 89-99 (2020) https://doi.org/10.1177/1475090219863956

8. Schlichting, 0 . Ship resistance in water of limited depth-resistance of sea-going vessels in shallow water (translated by Roemer, M.C, 1940), Technical report, Jahrbuch der STG, 35, 127-148 (1934).

9. Manen, J. D. V., \& Oossanen, P. V. Principles of Naval Architecture, Volume 2, The Society of Naval Architects and Marine Engineers, Jersy City, USA (1988).

10. ITTC. 28th International Towing Tank Conference. Recommended Procedures and Guidelines: Procedure Preparation, Conduct and Analysis of Speed/Power Trials. 7.5-04-01-01.1, Rev. 7 (2017). 
11. Lackenby, H. 'The Effect of Shallow Water on Ship Speed.' Article of The Shipbuilder and Marine Engine Builder, September (1963).

12. Raven, H.C. A New Correction Procedure for Shallow-Water Effects in Ship Speed Trials. Proceedings of PRADS 2016, Copenhagen, Denmark (2016).

13. Maimun, A., Faizul, A. A., Sian, A. Y., \& Yasser, M. A. Computation of Flow and Resistance around LNG Carrier in Deep and Shallow Water, The 7th Asia-Pacific Workshop on Marine Hydrodynamics (APHydro), Vladivostok, Russia (2014).

14. Raven, H.C. A Computational Study of Shallow-Water Effects on Ship Viscous Resistance. 29th Symposium on Naval Hydrodynamics, Gothenburg, Sweden (2012).

15. Barrass, C.B. Ship Design and Performance for Masters and Mates, pp 164-179, Elsevier Limited, Oxford, UK (2004).

16. 18th International Towing Tank Conference - ITTC Proceedings, Kobe Japan, Volume 1 (1987).

17. Marine EnvironeMEPC 308(73). 2018 Guidelines on The Method of Calculation of The Attained Energy Efficiency Design Index (EEDI) For New Ships, IMO (2018).

18. Holtrop, J., \& Mennen, G. G. J. An Approximate Power Prediction Method, International Shipbuilding Progress, vol. 29 (335), 166-170 (1982).

19. Holtrop, J. A Statistical Re-analysis of Resistance and Propulsion Data. International Shipbuilding Progress, vol. 31 (1984).

20. Holtrop, J. A Statistical Resistance Prediction Method with A Speed Dependent Form Factor, Paper Presented at SMSSH'88, Varna (1988).

21. 'Tide Table' by the Bangladesh Inland Water Transport Authority (BIWTA), Publishes each year for different river routes of Bangladesh, (2017 \& 2018).

22. BWDB. 'Flood Forecasting and Warning Centre', Bangladesh Water Development Board (BWDB), web: http://www.ffwc.gov.bd/ffwc_charts/waterlevel.php (Accessed: several times from the years of 2017 to 2019).

\section{Figures}




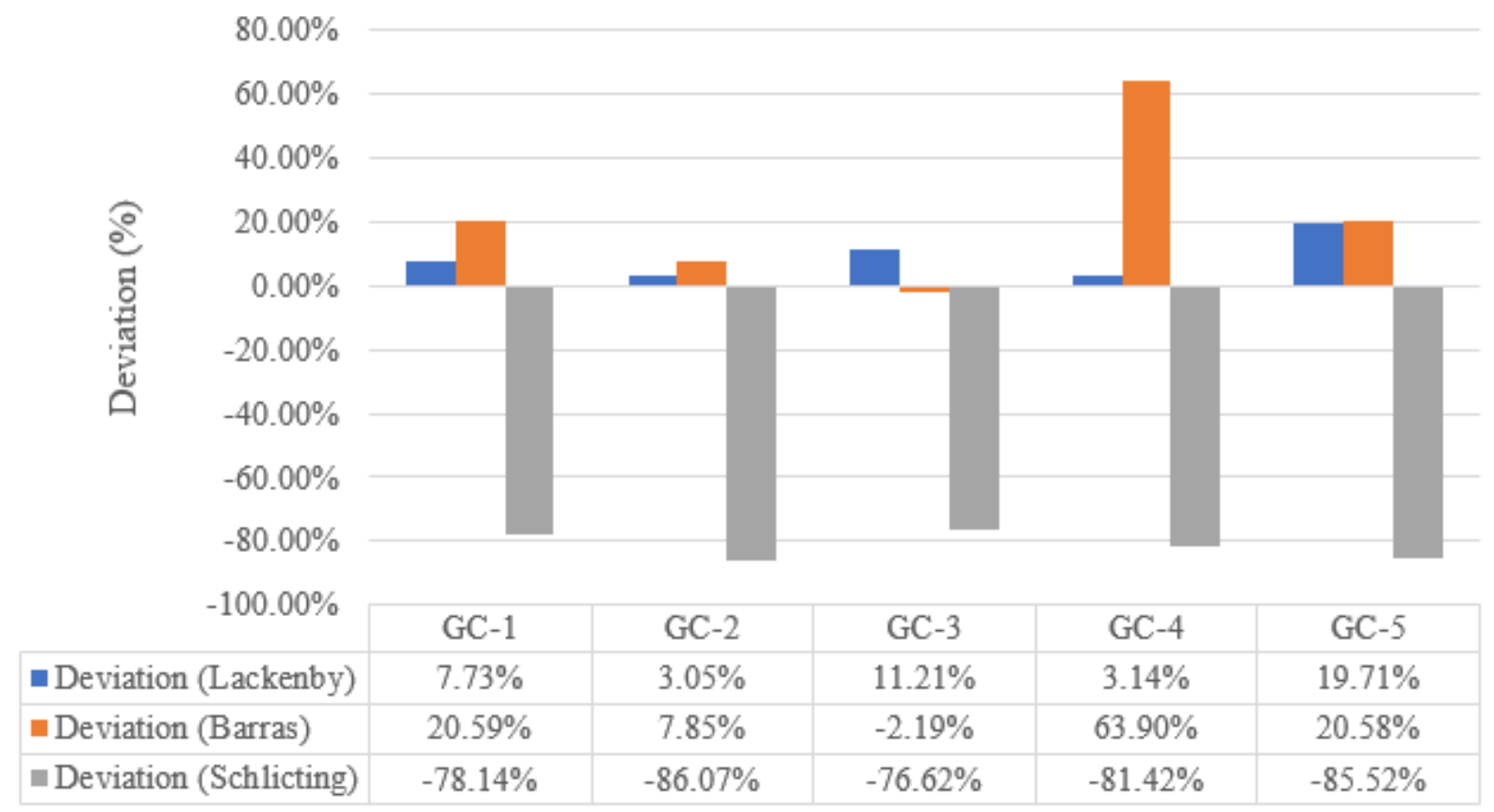

Figure 1

Deviation in shallow water effect by different methods from the investigated result for Cargo Ships

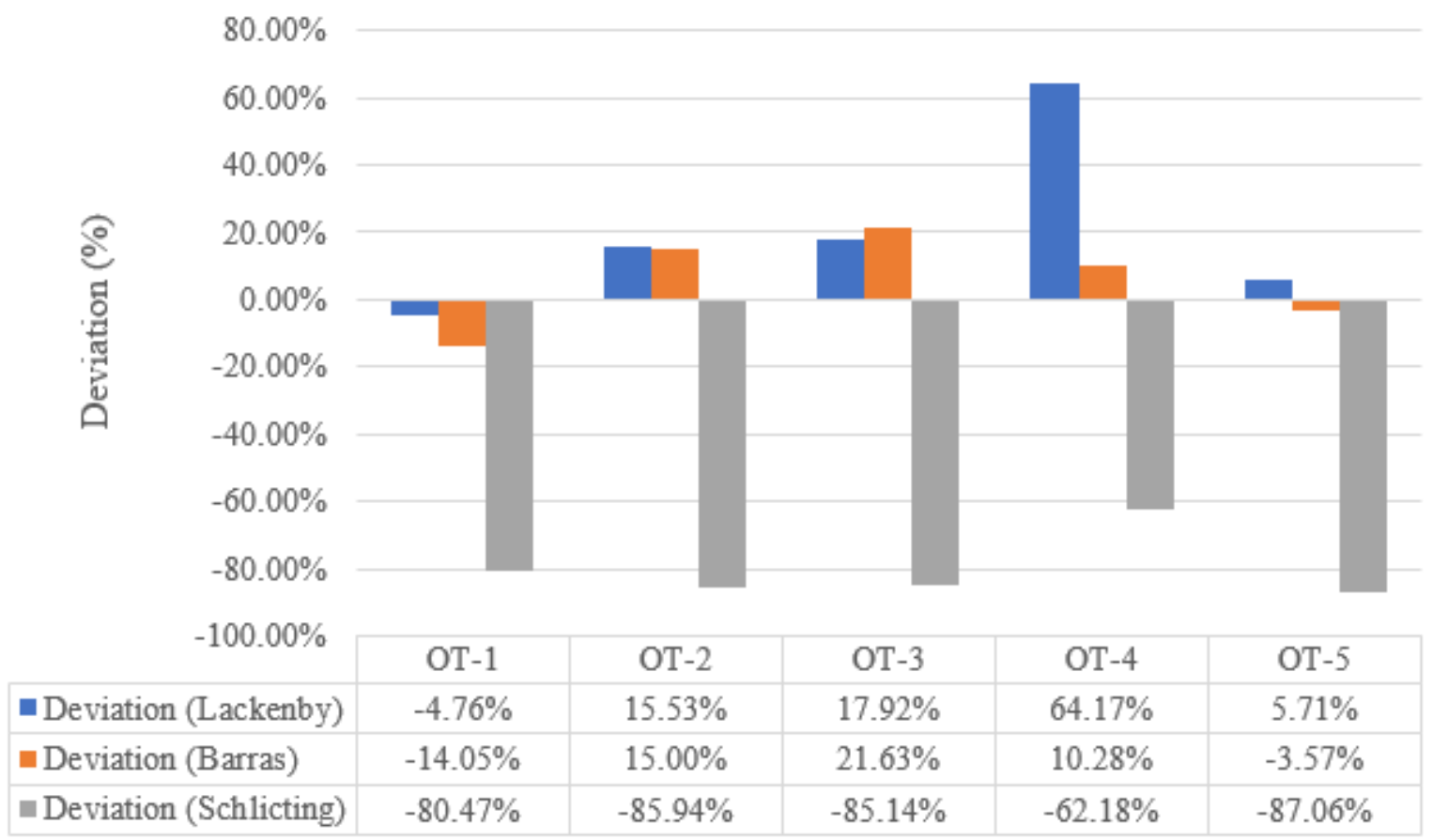

\section{Figure 2}

Deviation in shallow water effect by different methods from the investigated result for Oil Tankers 


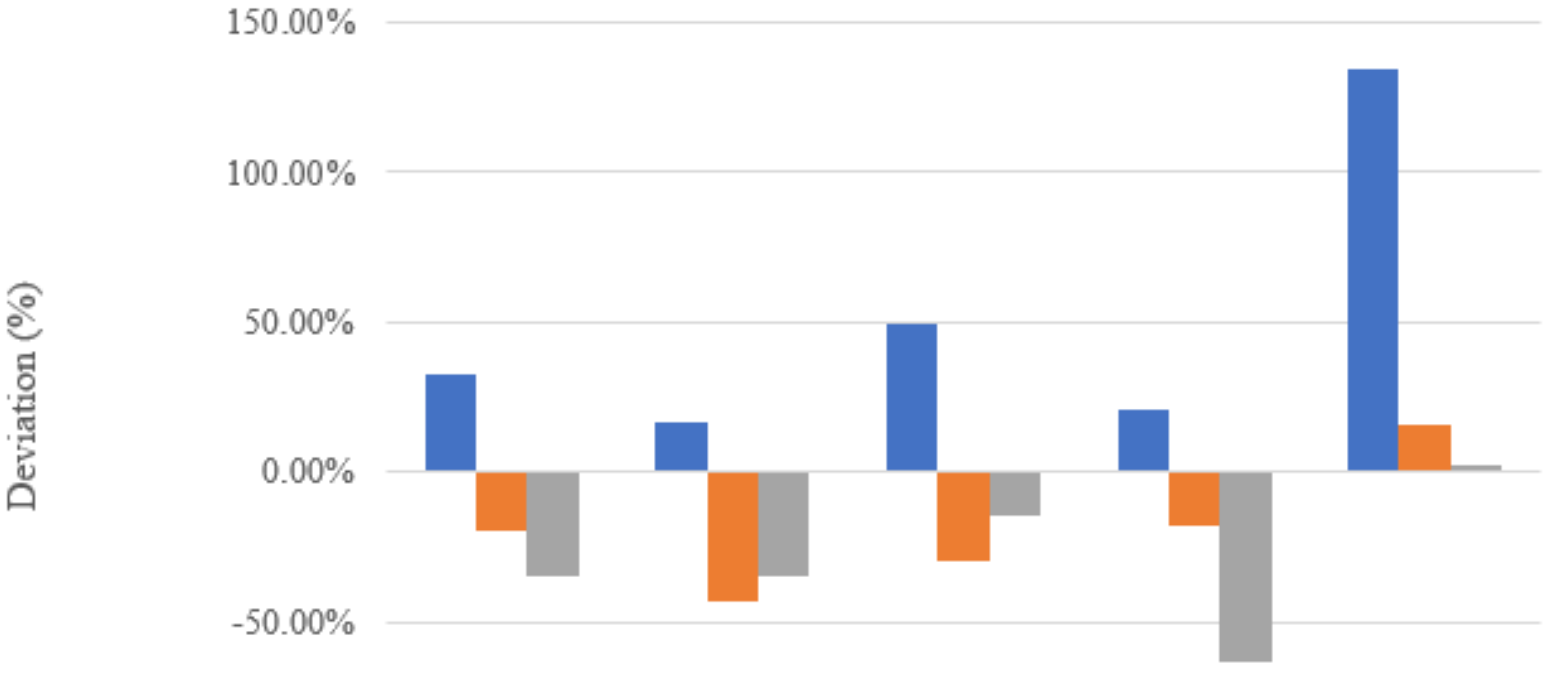

\begin{tabular}{|c|c|c|c|c|c|}
\hline$-100.00 \%$ & PV-1 & PV-2 & PV-3 & PV-4 & PV-5 \\
\hline Deviation (Lackenby) & $32.84 \%$ & $16.64 \%$ & $49.15 \%$ & $20.80 \%$ & $134.64 \%$ \\
\hline - Deviation (Barras) & $-19.91 \%$ & $-42.92 \%$ & $-29.60 \%$ & $-17.85 \%$ & $15.71 \%$ \\
\hline Deviation (Schlicting) & $-34.63 \%$ & $-35.02 \%$ & $-14.41 \%$ & $-63.46 \%$ & $1.90 \%$ \\
\hline
\end{tabular}

\section{Figure 3}

Deviation in shallow water effect by different methods from the investigated result for Passenger ships 